\title{
Indexicals and the Trinity: Two Non-Social Models
}

\author{
Scott M. Williams \\ Azusa Pacific University
}

\begin{abstract}
In recent analytic literature on the Trinity we have seen a variety of "social" models of the Trinity. By contrast there are few "non-social" models. One prominent "non-social" view is Brian Leftow's "Latin Trinity." I argue that the name of Leftow's model is not sufficiently descriptive in light of diverse models within Latin speaking theology. Next, I develop a new "non-social" model that is inspired by Richard of St. Victor's description of a person in conjunction with my appropriating insights about indexicals from David Kaplan and John Perry. I point out that the copula in tokens of statements like, "I am the Father," is an ambiguous term and when used by a certain divine person a different proposition is affirmed. Central to this model is the claim that the copula bears the "is of identity" and the "is of numerical sameness without identity." Further, I show that Leftow's model employs two concepts of "person," a Lockean one and a Boethian one, and mine employs Richard of St. Victor's. I describe Leftow's model as a "hard non-social" model and mine as a "soft non-social" model that is nearer to some social models. I conclude that Leftow's model is not the lone candidate among "nonsocial" models and that the variety of "non-social" models has yet to be exhausted.
\end{abstract}

\section{Introduction}

In recent years among analytic theologians we have seen diverse proposals within Social Trinitarianism [=ST] and Brian Leftow's rather forceful proposal for what he calls 'Latin Trinitarianism' [= LT]. One feature attractive to Social Trinitarians is the claim that each divine person is a 'self' capable of (e.g.,) eliciting first-person thoughts (and first-person volitions). The Father can think, 'I am God the Father', truly, but not the Son. By contrast, Leftow argues that to save Jewish monotheism Trinitarians ought to deny that there are three divine 'selves', that is, three distinct and discrete instances of divinity. Leftow contends that there is one and only one instance of divinity and that is God, who is the Father, is the Son, and is the Holy Spirit. After criticizing different versions of ST, Leftow encourages those interested in pursuing an orthodox Trinitarian theology to reconsider what he calls LT. 
Recently, Leftow's nomenclature, LT, has been challenged because it is historically misleading. I discuss this criticism in section two because it is relevant for having an accurate schema of models of the Trinity. As a matter of historical clarification, I point out diverse Latin Trinitarianisms that provide some background for my discussion of Leftow's version of LT and another that I develop.

In section three I discuss indexicals to the extent that they are required for understanding the two models of 'LT' that I discuss in sections four and five. My discussion of indexicals owes a great deal to David Kaplan and John Perry's accounts. One important feature of Perry's account is that numerically the same indexical token can be used to affirm different propositions relative to different contexts. I argue that Perry's position ought to allow for distinct agents using numerically the same indexical token simultaneously such that each agent can affirm different propositions by using numerically the same indexical token. Moreover, in section four I argue that a similar conclusion can be had regarding tokens of ambiguous signs like the copula "is."

Others may find other accounts of indexicals more compelling and so develop other models of indexicals and 'LT'. I would certainly welcome other such developments. In any case, I want to show that 'LT', or whatever it should be called, need not be limited to one model of indexicals and the Trinity: the model that Leftow defends.

\section{Nomenclature, "Latin Trinitarianism," and a Scholastic Tale}

In his influential article, “Anti Social Trinitarianism," Brian Leftow (1999) distinguishes between ST and LT. ST claims that each divine person is either a distinct and discrete instance of deity or that each person has numerically distinct mental powers. Each disjunct provides a sufficient condition for the persons' having an "I-you," psychological experience. LT, as Leftow (2004a; 2007) presents it, starts with the claim that (i) God is numerically one and only one divine substance (put otherwise, one and only one instance of deity), and then (ii) LT tries to explain the way in which there are three divine persons each of whom is God. ${ }^{1}$ I take Leftow to be suggesting that these two conditions are necessary and jointly sufficient for a model to count as a version of LT. In a footnote Leftow (2004a) adds that some partisans of LT advocate a strong account of divine simplicity (e.g., Thomas Aquinas) and others advocate a weaker account of divine simplicity (e.g., Duns Scotus). ${ }^{2}$

However, there are two things problematic with the name "Latin Trinitarianism." The first has to do with whether there were non-Latin-speaking theologians whose model of the Trinity satisfy the conditions for "Latin Trinitarianism." Recently, Richard Cross (2010) has shown that there are examples

\footnotetext{
${ }^{1}$ Leftow (2004a, 304); Leftow (2007, 357).

2 Note 3 of Leftow (2004a, 329) says: "LT's partisans up to Scotus all accept a strong doctrine of divine simplicity. So while they acknowledge that Father and Son stand in the generative relations of paternity and filiation, they deny that these relations are constituents of the Persons."
} 
in non-Latin-speaking Trinitarian theology that arguably satisfy the conditions that Leftow posits for 'LT'. Cross discusses the representative example of Gregory of Nyssa, an influential Greek-speaking theologian, and whose account of the Trinity satisfies 'LT'. Consequently, the name "Latin Trinitarianism" is too narrow. The name ought to be wide enough in signification to include relevant non-Latinspeaking theologians' accounts. If pushed, one might re-describe a model of the Trinity that satisfies the conditions for LT as, "Non-Social Trinitarianism" [=NST]. Nevertheless, as a matter of deference I will call Leftow's position, 'LT', because he calls it that.

The second problem has to do with whether Latin-speaking catholic Christian theologians are "Latin Trinitarians." I mentioned a moment ago that Leftow reports in a footnote that some partisans of 'LT' advocate a strong account of divine simplicity and others a weaker account of divine simplicity. In other words, the latter propose a constitutional account of divine persons, but the former resist talk of constituents somehow distinct from the divine nature. Surprisingly, however, Leftow (2007, 357) claims that, "[o]n LT, there is just one divine being, God. The three divine Persons are at bottom just God: they contain no constituent distinct from God" (Leftow 2007, 357 - emphasis mine). This statement seems to express a necessary condition of Leftow's 'LT'. But there are examples, which Leftow acknowledges, that satisfy what appeared to be the necessary and sufficient conditions for 'LT' but do not satisfy this additional condition. Hence, we find the following situation. On the one hand, Leftow reports that there are different versions of 'LT', but on the other hand he denies that 'LT' is consistent with any ('Latin') constitutional model of the Trinity. But he had already recognized that some partisans of 'LT' say that each divine person is constituted by the one and only one (instance of the) divine nature and a distinguishing personal attribute. Although Leftow introduces 'LT' as a general research program guided by the two conditions previously mentioned for 'LT', it turns out that his preferred species of 'LT' becomes "the Latin view" and other 'Latin' models are ignored because they are not the version of 'LT' that Leftow prefers. In practice it would seem that the term 'LT' has come to refer to Leftow's preferred version of 'LT'. ${ }^{3}$

At this point we are left asking, what reason is there for excluding 'Latin' constitutional models of the Trinity that "begin from the oneness of God, and try to explain just how one God can be three divine Persons" (Leftow 2004a, 304)? The only response that comes to mind is bias. Who are the partisans of 'Latin' constitutional models of the Trinity that Leftow is against? The better known advocates of a constitutional 'LT' model (among medieval scholars at least) are Henry of Ghent and Duns Scotus. ${ }^{4}$ There were many others too. ${ }^{5}$ The exclusion of

\footnotetext{
${ }^{3}$ Leftow (2004a, 304-305): “As Augustine, Boethius, Anselm and Thomas Aquinas pursued this project, let us call it Latin Trinitarianism (LT). I now sketch a Latin view of the Trinity and argue that it is coherent."

${ }^{4}$ For discussion of Henry of Ghent's constitutional model of the divine persons, see my (2012). See also Friedman $(2010,6-7,139-141)$.

${ }^{5}$ See Friedman (2012). Friedman (2010, 30ff.) mentions Walter Bruges, Eustace of Arras, Matthew of Aquasparta, Roger Marston, and John Pecham.
} 
certain Latin-speaking theologians from meriting the honorific title 'LT' is unfair and biased much like saying things like, "Any would be English speaker that spells the word colour as 'color' does not really speak English." Although Leftow has a particular research program in view (i.e. NST models that advocate a strong account of divine simplicity), calling it "Latin Trinitarianism," is uninformative. If pushed, one might re-describe Leftow's preferred version of 'LT' as "simple, non-social Trinitarianism" [=SNST] (though as I explain below this too requires further specification), and the other version of 'LT' as "constitutional non-social Trinitarianism" [=CNST].

Furthermore, if one were interested in making historical claims, then one ought to consider Russell Friedman's persuasive argument that there were two 'Latin' forms of (what I label) CNST. 6 On the one hand there were "Dominicans" who argued for the divine persons' being constituted by opposed relations (following Aquinas). On the other hand there were "Franciscans" who argued for the persons' being constituted by disparate types of emanation that are akin to causal relations (following Bonaventure). And yet there are further classifications to be made within the Franciscan fold. There was disagreement among Franciscans whether the Father's innascibility is a constitutive or non-constitutive personal property. (The Dominicans denied that innascibility is a personal property of the Father's in any sense.) How Franciscans answered this question had implications for whether the persons are distinguished by an absolute or relative personal attribute. Even more, some Franciscans, following Henry of Ghent, argued that the types of emanation for the Son and Holy Spirit are by way of intellect (for the Son) and will (for the Holy Spirit). At this point Scholasticism becomes intriguingly complex like the labyrinthine library in Umberto Eco's The Name of the Rose.

The name, "Latin Trinitarianism," is insufficiently informative as a historical description of Leftow's preferred version of 'LT' and for Leftow's own development of that version of 'LT'. His position is indeed "a Latin Trinity," but this is not adequately descriptive of Leftow's position as a species among its rivals. After all, some proponents of "Latin Trinitarianism" argued for such a strong doctrine of divine simplicity (i.e. a simple divine essence) that the persons are distinct through themselves without the divine essence being in any sense the truth-maker for a certain explanation of the persons' distinction. ${ }^{7}$ By contrast, Leftow tries to explain the distinction of the persons by appealing to God's distinct streams of life (see section four). It is clear, then, that even "simple, non-social Trinitarianism" is not sufficiently descriptive of Leftow's 'LT' - one would do well to describe it as "explanatory, simple, non-social Trinitarianism."

Lastly, Leftow engages with the texts of Thomas Aquinas as the inspiration for his own model, and claims that certain "causal relations" are what distinguish the persons. (See the quotation below.) What is ironic about Leftow's claim is that this is Bonaventure and the Franciscans' model of how the persons are distinct and

\footnotetext{
${ }^{6}$ See note 5 above.

${ }^{7}$ A well-known thirteenth century example (to medieval specialists at least) is Praepositinus, and some fourteenth century examples are Walter Chatton (d. 1343), Robert Holcot (d. 1349), and Gregory of Rimini (d. 1358). Cf. Friedman (2010, 137-170).
} 
not Thomas Aquinas's. For Aquinas, what ultimately explain the distinction of persons are opposed relations. I make no comment here about the coherence of Aquinas's own account of the causal relations between the persons other than that some of his immediate successors in Paris found fundamental problems with it. ${ }^{8}$ For Bonaventure and friends, what ultimately explain the distinction of persons are types of emanation (i.e. types of causal relations). ${ }^{9}$ Consider the following remark by Leftow.

The causal relations involved are those of the Trinitarian processions: the Father 'begetting' the Son, the Father and Son 'spirating' the Spirit. Nobody has ever claimed to explain how these work, so I'm at no disadvantage if I do not either. Every Trinitarian has claimed that whatever these relations amount to, they yield distinct Persons who are the same God (Leftow 2004a, 314).

It is false to claim that "nobody" has ever tried to explain the causal relations of begetting and spirating. Franciscan's like Henry of Ghent and Duns Scotus each tried to explain these (whether they succeeded is another question). ${ }^{10}$ Perhaps one reason that these Franciscan explanations of the causal relations do not show up is that Leftow has excluded their versions of 'LT' from "the Latin view." (There is no space here to discuss Franciscan causal explanations; still, the version of 'LT' that I suggest in section four is inspired by their accounts.) These, then, are some reasons that it is important to be as historically sensitive as possible: the things we exclude may contain things that we are searching after: e.g., the overlooked clues in the drama of The Name of the Rose.

In section four I distinguish Leftow's version of 'LT' and my proposed constitutional version of 'LT'. In section five it will become clear why I describe Leftow's position as "hard LT" and my alternative as "soft LT." But first we must get clear on indexicals.

\section{A Select Summary of Indexicals}

What are indexicals? David Braun gives a helpful summary.

The indexicals that philosophers have studied most are the pronouns 'I', 'he', 'she', 'this', and 'that'; the adverbs 'here', 'now', 'actually', 'presently', 'today', 'yesterday', and 'tomorrow'; and the adjectives 'my', 'his', 'her','actual', and present'. This list comes (more

\footnotetext{
${ }^{8}$ Cf. Williams (2010a).

${ }^{9}$ Cf. Friedman (2010, 6-30). Also, see my (2010b).

10 For discussion of Henry of Ghent and Duns Scotus's account of internal divine production, cf. Paasch (2012). On many points I am in agreement with Paasch's account. However, I disagree with Paasch's interpretation of metaphysical powers according to Henry of Ghent and some details regarding Henry's account of production; cf. Williams (2011, 125-144).
} 
or less) from David Kaplan (1989a), whose work on indexicals is perhaps the most influential in the field.

An indexical's referent and content are determined by its linguistic meaning (character) and such contextual factors as the time, location, and intentions of the speaker. Indexicals are also commonly called context-sensitive expressions because their contents vary from context to context. The term 'indexical' is commonly (though not always) restricted to simple expressions, such as 'I' and 'today', whereas the term 'context-sensitive' is often applied both to simple indexicals and to complex expressions that contain simple indexicals, such as 'the man I love' and 'I am female' (Braun 2012, §1.1).

What is unique to an indexical is that its referent and content "are determined by its linguistic meaning (character) and such contextual factors as time, location, and intentions of the speaker." Fluent English speakers know the linguistic meaning of the pronoun, 'I', and know that its reference is fixed by the one who says 'I.' When Peter says, "I am happy," 'I' refers to Peter (and only Peter); when Paul says, "I am sorrowful," 'I' refer to Paul (and only Paul). Although Peter and Paul use the same pronoun, something is added when Peter (or Paul) use it, namely the reference of ' $I$ ' gets determined by the one saying "I" at a given time and place. As Braun puts it, indexicals like 'I' have an automatic reference that is determined by the one speaking it.

Moreover, the referent of an indexical like 'yesterday' is determined by the time of the speaker's saying, "yesterday." If I say, "yesterday I took a nap," the referent of 'yesterday' is June $7^{\text {th }}, 2012$. But if I say, "yesterday I took a nap," on July $7^{\text {th }}, 2012$, then the referent of 'yesterday' is July $6^{\text {th }}, 2012$. Further, the referent of an indexical like 'here' is determined (roughly) by the place of a speaker when a speaker says, "It is hot here." When I say, "it is hot here," and I am in Notre Dame, Indiana, the referent of 'here' is Notre Dame, Indiana. There is much more to be said about how place determines some indexicals but I leave those complications to the side since they are irrelevant for my purposes. Of these three indices (speaker, time, and place), the one relevant for determining the reference of ' $\mathrm{I}$ ' is the person saying "I".

How might we understand the content or meaning of an indexical token of the sentence, "I am female"? Braun summarizes Kaplan's answer to this question.

In Kaplan's theory, linguistic expressions have contents in, or with respect to, contexts. Each context has at least an agent, time, location, and possible world associated with it. The content of 'I' with respect to a context $c$ is the agent of $c$. [...] The content of a predicate, with respect to a context, is a property or relation. The content of a sentence, with respect to a context, is a structured proposition, that is, a proposition can have individuals, properties, and relations as constituents. The content of a sentence $S$ with respect to $c$ is made up of the content of the words in $S$ with respect to $c$. 
To illustrate, consider the sentence "I am female." Suppose that the agent of context $c$ is Fred. Then the content of " $\mathrm{I}$ " in $c$ is Fred himself, while the content "is female" in $c$ is the property of being female. The content of the whole sentences, in $c$, is a proposition whose constituents are just two items. We can represent this proposition with the following ordered pair. <Fred, being female>. The content of "I" with respect to a context $c^{*}$ in which Wilma is the agent is Wilma herself, and the content of "I am female" in $c^{*}$ is the proposition <Wilma, being female>. Thus the word "I" and the sentence "I am female" have different contents in different contexts.

The content of a sentence, with respect to a context, is a proposition, and that proposition has a truth value at any possible world, including the world of the context. Suppose that $w$ is the world of contexts $c$ and $c^{*}$ above, in which Fred and Wilma are the agents, respectively. The content of "I am female", with respect to context $c$ is the proposition $<$ Fred, being female>. This proposition is false at $w$. But the content of "I am female" with respect to context $c^{*}$ is the proposition that Wilma is female, and this proposition is true with respect to $w$ (Braun 2012, §3.2).

For Kaplan an expression or sentence (e.g., "I am female") can be relative to diverse contexts such that an expression-in-a-context entails a proposition that is not identical to another proposition entailed by the expression in another context. When Fred says, "I am female," the proposition is <Fred, being female $>$. When Wilma says, "I am female," the proposition is <Wilma, being female $>$.

It is clear enough that the same expression or sentence can be instantiated in diverse contexts (indices). Fred and Wilma have numerically distinct tokens of the sentence "I am female." But can numerically the same token of an expression be relativized to different contexts? Could Wilma's token of "I am female," be subject to contexts other than Wilma's using it? John Perry thinks so.

Perry distinguishes between a person's uttering or using a token, and the token itself; he also mentions the production of a token. Perry says,

The term "token" is used in two different ways in the literature: for the act of speaking, writing, or otherwise using language and for an object that is produced by, or at least used in, such an act. I use "utterance" for the first sense. Utterances are intentional acts. The term "utterance" often connotes spoken language, but as I use it an utterance may involve speech, writing, typing, gestures or any other sort of linguistic activity. I use "token" in the second sense, in the way Reichenbach used it when he said that a certain token was to be found on a certain page of a certain copy of a book. Tokens, in this sense, are traces left by utterances. [...]

An utterance may involve a token, but not be the act of producing it. My wife Frenchie and I were once Resident Fellows in a dormitory at Stanford, eating with the students each evening in the 
cafeteria. If she went to dinner before I returned, she would write on a small blackboard on the counter, "I have gone to the cafeteria," and set it on the table near the front door of our apartment. I would put it back on the counter. There was no need for her to write out the message anew each time I was late; if the blackboard had not been used for something else in the interim, she could simply move it from the counter back to the table. Frenchie used the same token to say different things on different days. Each use of the token was a separate utterance.

One can imagine the same token being reused as a token of a different type of sentence. Suppose there is a sign in a flying school, intended to warn would-be pilots: "Flying planes can be dangerous." The flying school goes bankrupt; the manager of a park near the airport buys the sign and puts it next to a sign that prohibits walking on high tightropes. In its new use the sign is a token of a type with a different syntax and a different meaning than in its original use (Perry 2000, 318-9).

Perry argues that numerically the same token can be used "to say different things" relative to different contexts. This is most easily shown in the case of tokens that are written down. The content and referent of a written token, "flying planes can be dangerous," is determined by its location. A person can produce a token and use it; and, a person can use a token that has already been produced. In Perry's example, time is a relevant index; at one time the sign is at the flying school and at another time it is at a park.

It is important to point out the significance of his distinction between the agent that produces a token, and an agent that uses a token. Some might be tempted to conflate this distinction. One tell-tale sign of this conflation is if a philosopher talks about the "speaker" of a token of "I," such that the speaker is identical to the agent that produces the token. This conflation might be understandable in examples of a person's saying out-loud, "I am happy." In such cases the producer of the token and the agent that uses it are usually the same individual. However, this sort of example should not be taken as paradigmatic for all cases of the indexical, "I." Perry's example shows that an agent's production of the token, "I" is not identical to an agent's use of the token.

Consider another Perry-style example. Suppose that Peter produces (i.e. writes) a sign that reads, "I am happy," and that Peter uses this sign by holding it up. Peter affirms that Peter is happy. Later, Peter puts the sign on the ground and Paul picks up the same sign and holds it up such that Paul affirms that Paul is happy. Paul uses numerically the same token as Peter did, yet when Paul uses it he affirms something different than Peter. Paul says that Paul is happy. Notice that Paul did not produce the sign, he only used it. This Perry-style example shows that an agent's production of a token is not identical to an agent's use of this token.

Moreover, the individual agent that produces a token need not be the same agent that uses this token. Peter and Paul can use numerically the same written sign at different times. But this need not be the case. Peter and Paul could each hold up 
numerically the same written token of, "I am happy," at the same time. Peter asserts that Peter is happy, and Paul asserts that Paul is happy. Numerically the same token of "I," can in fact refer to different persons so long as different persons are using it. If Peter had produced a sign that reads, "We are happy," and Peter and Paul both use it, then each would be asserting something quite different than if the sign each uses read, "I am happy." The content (the linguistic meaning) of "I" (or "we") contributes to what is asserted by the agent(s). It does not seem right to claim (as Leftow does) that, "a token of 'I' cannot refer to many speakers. Doing so is the job of 'we', not 'I' " (Leftow 2004b, 226). With these Perry-style examples to hand we have reason to believe that numerically the same token of "I" can refer to different persons if different persons use this token, whether at different times or simultaneously.

Furthermore, the context-sensitivity of numerically the same indexical token is not unique to Perry-style examples of indexicals. In section four I argue that an agent's using an ambiguous sign determines the proposition that is affirmed. What is said by means of an ambiguous token is context-sensitive. Consider ambiguous tokens such as Bilbo Baggins saying to Gandalf, "Good Morning!"

"Good Morning!" said Bilbo, and he meant it. The sun was shining, and the grass was very green. But Gandalf looked at him from under long bushy eyebrows that stuck out further than the brim of his shady hat.

"What do you mean?" he said. "Do you wish me a good morning, or mean that it is a good morning whether I want it or not; or that you feel good this morning; or that it is a morning to be good on?"

"All of them at once," said Bilbo (Tolkien 1973, 17-8).

Bilbo uses the token, "Good Morning!" to say several things "at once." He can do this because the sign that he uses bears multiple meanings. This token's bearing multiple meanings is why Gandalf replies, "What do you mean?" In response, we learn that Bilbo says different things by means of the same ambiguous token. Bilbo can say so many things because of the ambiguity of the sign and the different contexts (the sun is shining, the grass is green, Bilbo speaks to Gandalf, etc.) in which Bilbo uses it. Bilbo exploits the ambiguity of this sign to say many things "all [...] at once."

What is perplexing is whether there are any limits to what Bilbo is saying. How vast is the range of things that can be said by means of an ambiguous sign? It is reasonable to suppose that the range is limited by whatever semantic or syntactic properties the sign bears and the contexts (indices) in which an ambiguous sign is used. I will return to ambiguity and Bilbo's use of an ambiguous sign in section four. For now I only wish to suggest that ambiguous signs are context-sensitive like indexicals.

In this (all too brief) summary of indexicals we see that the referent of an indexical expression like "I," and the proposition entailed by it, depends upon the person using the token of "I." Moreover, an indexical expression like "I" automatically refers to the person using it. Lastly, we see that numerically the same 
token of an expression can be relative to diverse contexts and so be used to affirm diverse propositions.

\section{Non-Social I's}

The main motivation for Leftow's 'LT' is that Jewish monotheism should matter to Christians. If Christians worship the same God as Jews, then they worship numerically one God; for Jews are monotheists. Monotheism ought to matter to Trinitarian Christians. It remains to be seen what options there are for sympathizers of 'LT'. Leftow argues for what he seems to take to be the account available to friends of 'LT'. I suggest that there are at least two models of indexicals and 'LT': hard 'LT', which is Leftow's version, and soft 'LT'.

On hard 'LT,' there is one God because there is one divine agent, God. On this view God lives three lives (Father, Son, and Holy Spirit). One of God's streams of life is the Father; another of God's streams of life is the Son; and, still another of God's streams of life is the Holy Spirit. God lives three lives such that each life is a part of God's inner-life (Leftow 2004a, 328; 2007, 374). The persons "have lives which add up to the life of one God" (Leftow 2007, 375). Inspired by John Locke's events-based account of personal identity, Leftow adds that the persons are God's mental events: God's distinct streams of consciousness. ${ }^{11}$ If God has the thought, "I am God the Father," there is no question who has this thought; God has it. Nevertheless, only God at his fatherly stream of life thinks, "I am God the Father," truly. The referent of "I am God the Father," is God (the agent) at God's fatherly stream of life. By contrast, the Son cannot think, "I am God the Father," truly; but can think, "I am the God who is (at another point in His life) the Father" (Leftow 2004a, 327).

Leftow is emphatic that the persons are not contingent attributes of God, but are "eternal, necessary, and intrinsic features of God's life, one which would be there even if there were no creatures" (Leftow 2007, 374). What is clear is that for Leftow the persons are not agents; they are God's distinct streams of mental events - they are parts of God's inner-life. God, at bottom, is the only divine agent even though God's agency is necessarily at, or in, one (or more) of God's lives or streams of consciousness. In his early article, "Anti Social Trinitarianism" (1999), we can see Leftow's position already emerging when he said,

In [Latin Trinitiarianism], the Son is not discrete from the other Persons. For the Son to be in the forefront of an act is just for God to be more prominent in one role (or state, etc.) than he is in others (Leftow 2004b, 238).

11 "I now add that these three streams of consciousness and the Persons they generate are eternal, necessary, intrinsic features of the divine inner life." (Leftow 2007, 374) 
There is only one metaphysical agent of all divine thoughts and that is God. This model of indexicals and the Trinity might be appealing because of its proximity to monotheism.

However, a downside of this hard 'LT' model is that it takes away any theological intuitions or beliefs that the divine persons are agents. On the hard version, there is only one divine agent and that is God. (After all, Leftow refers to God with the personal pronoun "he." I will return to this point in section five.) But suppose we are persuaded by Leftow's criticisms of ST, are inclined toward 'LT', and yet wish there was a way to be not quite as non-social as hard 'LT'. In this case, a soft 'LT' model might be appealing.

On soft 'LT' there are three metaphysical agents (Father, Son, and Holy Spirit). Each divine person is constituted by two items: the one and only one instance of the divine nature and an incommunicable personal attribute (e.g., begetting). Note that this (instance of the) divine nature is communicable: it can be a constituent of more than one person. The Father is constituted by the one and only one instance of the divine nature and begetting. The Son is constituted by numerically the same instance of the divine nature as the Father's and being begotten. Lastly, the Holy Spirit is constituted by numerically the same instance of the divine nature and being spirated. What explains the Son's and Holy Spirit's having this divine nature as a constituent is that a divine agent (necessarily) communicates it to this person. The Father necessarily communicates this divine nature to the Son, and the Father and Son necessarily communicate this divine nature to the Holy Spirit.

Taking cues from Richard of St. Victor, Henry of Ghent, Duns Scotus, Michael Rea and Jeffrey Brower, soft 'LT' says that no divine person is identical (in Leibniz's sense of identity) to this divine nature, but each divine person is essentially numerically the same thing as the divine nature without being identical to it (Brower et. al. 2005). ${ }^{12}$ Following Henry of Ghent, the divine nature is a sui generis singular existing universal thing that necessarily is a constituent of the Father, Son, and Holy Spirit.

Further, this divine nature is each person's power-pack, so to speak. The Father can generate the Son because his active power to do so is grounded in the divine nature. The divine nature can be communicated to the Son because it is communicable. Although the Son has this active power to generate a Son, given that he has numerically the same divine nature as a constituent, he does not exercise this active power because the Father has already exercised it. (One argument for this is that the Son perfects the divine power for generating a Son, and so no further exercise of this power is required.)

Why suppose that the persons are numerically the same thing as the divine nature without being identical to it? Items that are identical have exactly the same modal features. So, consider some (supposed) modal facts. The Father can generate the Son, but the Son cannot generate himself. The divine nature can, but the Father

\footnotetext{
12 See also, Brower (2004); Williams (2012, 115-133, 137-145, esp. 39-140); and lastly Cross (2012). Cross explains why the divine nature is better thought of as a universal than like an "immaterial stuff" Brower and Rea suggest.
} 
cannot, be communicated to the Son. The Son can be generated, but the Father cannot be generated. Similar points can be made about the Holy Spirit. Since Christians believe that there cannot be but three divine persons, we can say that three divine persons are essentially numerically the same thing as the divine nature without being identical to it. Likewise, the persons are essentially numerically the same divine nature as each other but are not identical to each other.

Furthermore, on soft 'LT' this singular divine nature does not exist because it is the end term of some agent's production. Instead, this divine nature exists per se and is a constituent of the Father's. It is a concrete item (rather than an abstract one) that is the ground of the divine persons' powers. Concrete items either can do something or something can be done to them. In this case, this singular divine nature can be (eternally) communicated to a divine person that is the end term of a divine agent's production. The Father communicates this singular divine nature to the Son through (eternally) generating the Son, and to the Holy Spirit through (eternally) spirating the Holy Spirit with the Son. ${ }^{13}$

Although the divine nature exists per se, the divine nature itself is not a person; the divine nature is not someone but something. According to Richard of St. Victor, contra Boethius, a person is an incommunicable existent of an intellectual nature. ${ }^{14}$ (I discuss Boethius's and Richard's concepts of 'person' in section five below.) The one and only one instance of the divine nature is not a person because it is communicable. But the Father, Son, and Holy Spirit are persons because each is jointly constituted by an incommunicable attribute (begetting, being begotten, or being spirated, respectively) and the communicable divine nature.

If one were to ask what the referent of the name "God" is for soft 'LT', it would depend on what is intended. ${ }^{15}$ This name can be used to refer to divine power, e.g. being omniscient. It can be used to refer to someone who is intrinsically divine. The former use can be satisfied by the one and only instance of the divine nature; the latter use can be satisfied by any divine person. The term 'Trinity' refers to the Father, Son, and Holy Spirit, and not to an overlapping collection of the persons.

Turning to the question of indexicals, on a divine-simplicity version of soft 'LT' the divine nature grounds tokens like, "I am the divine Father." (Further below I explain how soft 'LT' interprets the proposition affirmed when an agent uses this token.) The Father uses this token, and by virtue of communicating the divine nature to the Son, the Father communicates this token to the Son who uses this

\footnotetext{
${ }^{13}$ See note 10 above.

${ }^{14}$ See note 17 below. Richard's definition was influential for later scholastics like John Duns Scotus, but much less so for Thomas Aquinas. Aquinas mentions Richard's definition in passing but neither explains it nor Richard's criticism of Boethius; cf. Thomas Aquinas, Summa Theologicae, 1-1 q.29 a.3 ad 4. For discussion of Duns Scotus's reception of Richard's definition, cf. Cross $(2005,159)$. ${ }^{15} \mathrm{Cf}$. Henry of Ghent, Summa Quaestionum Ordinariarium [henceforth = SQO], 75.2, f. 296vA (translation mine): "'God', then, signifies a singular thing from which the name is established, and it stands indefinitely for several supposites [=persons]." Ibid., $S Q O, 28,3$, f.166vI-167vP; $S Q O, 53,10$, f.72rM; SQO, 54, 3, f.81vY, f.84rF; SQO, 54, 9, f.104vC; $S Q O, 56,3$, f.115vX; $S Q O, 71,2$ ad 3, f.250vF; $S Q 0,75,2$, f.295rK.
} 
token. Likewise, by virtue of the Father and Son communicating this divine nature to the Holy Spirit, they communicate this token to the Holy Spirit who uses this token. Thus, the Father, Son, and Holy Spirit each use this token, "I am the divine Father." The reason why each person uses this token is that such tokens are grounded in the singular divine nature that is a constituent of each person.

On a less 'simple' version of soft 'LT' we would say that the Father produces the token, "I am the divine Father," uses it, and shares it with the Son and Holy Spirit. This token would be a necessary attribute of the persons. It would not be grounded in the divine nature but would be a singular quality that ontologically depends on the divine nature. (One must be intellectual to use such a token.) The Father shares this token because the Father necessarily shares everything with the Son and Holy Spirit that he can. What the Father cannot share with them is his incommunicable personal attribute and whatever is incompatible with the other persons.

At the end of section three I said,

The referent of an indexical expression (e.g., "I") depends upon the person using it. Moreover, an indexical expression like "I" automatically refers to the person using it. Lastly, numerically the same instantiation of an expression (i.e. a token) can be relative to diverse contexts and so entail diverse propositions relative to diverse contexts.

Following Kaplan and Perry, soft 'LT' says that the referent and content of "I" in tokens such as "I am the divine Father," are determined by the agent using this token. The Son's using this token entails that the "I" refers to the Son and not to (e.g.)) the Father. But what about the rest of the sentence, "am the divine Father"? If the semantic content and syntax of "am the divine Father" were identical in each of the Father, Son, and Holy Spirit's use of it, then e.g., the Son would assert something false, namely that the Son is identical to the Father. But no divine person asserts falsehoods. If the Son uses this token, then his using it must entail that he affirms a different proposition than what the Father affirms. To resolve this issue soft 'LT' points out that the copula in, "am the divine Father," is an ambiguous sign. This does not imply that a divine person has an ambiguous or confused thought. Rather, a divine person uses an ambiguous sign in a determined way: it is determined by the index of the agent.

Ambiguous signs bear diverse syntactic structures, or semantic properties, or both (Sennet 2011, section 3). Consider again Bilbo Baggins's, “Good Morning!” This token bears diverse syntactic structures and semantic contents, and Bilbo uses these diverse features in different contexts simultaneously. Bilbo not only describes some objects (e.g., the grass, the day), but also issues a command to Gandalf. The copula, for example, bears different semantic properties: the 'is' of identity, the 'is' of predication, the 'is' of contingent numerical sameness without identity, and the 'is' of essential numerical sameness without identity ${ }^{16}$ (Brower et. al. 2005). In the case

16 Cf. Brower et. al. $(2005,71)$. 
of the divine token, "I am the divine Father," the way in which the copula is used depends upon the agent. If the Father uses this token and asserts no falsehoods, then the referent of " $\mathrm{I}$ " is the Father and the 'is' of identity is used. If the Son uses this token and asserts no falsehoods, then the referent of "I" is the Son and the 'is' of essential numerical sameness without identity is used. Likewise, if the Holy Spirit uses this token and asserts no falsehoods, then the referent of "I" is the Holy Spirit and the 'is' of essential numerical sameness without identity is used. In brief, if the Son uses this token, "I am the divine Father," truly, then the Son's using this token entails that the Son affirms the proposition, <Son, essentially numerically the same divine nature as the Father without being identical to the Father $>$. If the Holy Spirit uses this token, then the Holy Spirit's using it entails that the Holy Spirit affirms the proposition, <Holy Spirit, essentially numerically the same divine nature as the Father without being identical to the Father>.

Perry argued that numerically the same indexical token can be used to affirm different propositions relative to different indices. Soft 'LT' requires that not only is Perry right, but also that Perry's claim can be extended to numerically the same ambiguous tokens. In Perry's examples, time or place or both are the relevant indices. In my Perry-style example, the agent(s) is the relevant index. Indeed, more than one agent can use numerically the same indexical and ambiguous token (e.g., "I am the divine Father,") and in so doing assert different propositions.

At this point one might ask, if distinct agents can use numerically the same indexical and ambiguous token simultaneously, and in so doing assert different propositions by means of this token, then what would distinguish numerically distinct indexical and ambiguous tokens of the same type? It would have seemed that indexical and ambiguous tokens of the same type are numerically distinct if and only if they entail different propositions. But Perry-style examples show that the condition of entailing different propositions is neither necessary nor sufficient for numerically distinct indexical and ambiguous tokens of the same type. For, one indexical and ambiguous token can be relative to different contexts and so entail different propositions. There are several options for what might individuate indexical and ambiguous tokens of the same type. One option is that a primitive thisness (haecceity) makes indexical tokens of the same type numerically distinct. But whatever explanation is employed, one option not available is that the agent or user of an indexical and ambiguous token individuates them. If the agent individuates indexical and ambiguous tokens of the same type, then more than one agent could not use numerically the same indexical token as other agents. But the consequent is false, and so the antecedent is false too.

We can now compare the hard and soft versions of 'LT'. On hard 'LT' the referent of "I am God the Father," is God (who is the agent) at God's fatherly life. But on soft 'LT', the referent of a similar indexical expression, "I am the divine Father," is relative to the divine person using this token; likewise, the particular semantic property of the copula that is used, is relative to the agent. On soft 'LT' each divine person is an agent; this is what renders soft 'LT' closer to ST. What unite hard 'LT' and soft 'LT' are the following. Each starts with the claim that there is numerically one and only one instance of deity; each aims to explain how there can be three divine persons; each says that there is no "I-you" psychological phenomenon 
between divine persons; and, each maintains that there is only one divine token of each type that God, or the persons, have.

\section{Concepts of 'Person'}

Hard and soft 'LT' employ different concepts 'person'. By making explicit these diverse concepts, we will be better situated to understand an important way in which hard and soft 'LT' differ.

Boethius put forward the classic definition of a person: a person is "an individual substance of a rational nature" (Boethius 1973, 85). His definition was in response to a question about the incarnation of the Son of God. For Boethius, this definition seemed satisfactory when thinking about human persons. However, in Book Four of his De Trinitate Richard of St. Victor considered the Latin claim that there are three divine persons (persona) and noticed a problem with the applicability of Boethius's definition for divine persons. If we were to accept Boethius's definition, then there could not be three divine persons because there is only one divine substance. But there are three divine persons. Consequently, Richard aimed to rectify this problem by developing a satisfactory general account of a person, and not by means of an ad hoc account for divine persons. ${ }^{17}$ In what follows I compare Boethius's and Richard's concepts of 'person'.

Whereas Boethius supposed that a person is "an individual substance of a rational nature," Richard argues that a person is "an incommunicable existent of an intellectual nature." Boethius's 'individual substance' is a distinct and discrete instance of a natural kind. If there are three human persons, then there are three human substances - three distinct and discrete instances of humanity. But for Richard the notion of an 'individual substance' is too narrow because it does not work in the case of divine persons. Instead, we should begin by saying that a person is incommunicable with anything or anyone else (Richard of St. Victor 1958, 180). On Richard's analysis a person's 'existence' indicates the origin of a person's having the nature that the person has. Richard claims that the term 'existence' can be broken down into "ex" ("from") and "sistere" ("to stand"). ${ }^{18}$ This suggests that a person has his or her nature from someone or something, and stands out from all else having been constituted with this nature in this way. We might say that a person's rigid designators include the person's incommunicable origin. God the Father has the divine nature from no other person, but God the Son has the divine nature from the Father. And, the Holy Spirit has the divine nature from the Father and Son. For Richard, then, a person's being an 'incommunicable existent' entails that a person has his or her nature in a unique way that no one else could.

Boethius said that a person is an 'individual substance of a rational nature', but Richard says that a person is an incommunicable existent of an intellectual

\footnotetext{
17 See Richard of St. Victor (1958, 186-187). See also, ibid., De Trinitate, 4, 23, p. 188, ln. 19 (translation mine), "In any case, this [definition of person] is common to every human substance, angelic substance, and divine substance."

${ }^{18}$ (Richard of St. Victor 1958, 4,11-12, pp. 173-175)
} 
nature'. The difference between 'rational' and 'intellectual' is irrelevant for my purposes. At minimum both are saying that a person can have beliefs and can perform voluntary actions. The relevant difference is Boethius's claim that a person is "an individual substance of a rational nature" and Richard's proposed correction that a person is "an incommunicable existent of an intellectual nature." On Boethius's definition we can say only that there is one divine person because there is only one (instance of the) divine nature; but with Richard this problem evaporates. Richard claims that there is one and only one (instance of the) divine nature, and that the divine nature cannot count as a person because it is communicable. The one divine nature can be a constituent of more than one person. Each divine person is constituted by the communicable (and one and only instance of the) divine nature and by an incommunicable personal attribute. If pushed, Richard's metaphysical account of a divine person might be expressed in contemporary language by saying that the divine nature is a communicable trope and the distinguishing personal attributes are incommunicable tropes. In the case of divine persons what satisfies the definition of 'person' is a composite of the communicable divine nature and an incommunicable personal attribute.

If we turn to their Trinitarian theologies we find that Boethius says that there are three persons by suggesting that the one (and only one) divine substance is related to itself: as Father of the Son, as Son of the Father, and as Holy Spirit of the Father and Son. ${ }^{19}$ The personal relations are predicated of God (the divine substance). Richard agrees that there is only one divine substance or nature and that the persons are distinct by relations - that is, relations of order of origin (i.e. the Father is from himself, the Son is from the Father, and the Holy Spirit is from the Father and Son).$^{20}$ But given his more general understanding of a 'person', Richard can say that the persons are related to one another. The Father is an incommunicable existent related to the Son who is another incommunicable existent. The Father is the "cause" of the Son..$^{21}$ The Son is a "person from a person, an existent from an existent, one from only one, processible from inprocessible, generable from ingenerable, lastly, one [person] immediately clinging to one [person], because one proceeds from one immediately."22 Note that Richard says that the Son is "generable" from the Father who is "ingenerable." I take this as evidence that the Son has a modal feature that the Father does not have. The same person cannot generate and be generated with respect to numerically the same generation. Hence, the Son and Father are not identical. ${ }^{23}$

In sum, for Boethius, God is related in diverse ways to himself. For Richard, the divine persons are related to each other. It should be no surprise, then, that the two models of 'LT' discussed in section four roughly follow these different accounts

\footnotetext{
${ }^{19}$ (Boethius 1973, Book V, 27, lines 17-28 \& 57)

20 (Richard of St. Victor 1958, 1, 11-17, pp. 95-100; and, 5, 3-14, pp. 197-215)

${ }^{21}$ Ibid., 5, 7, p. 203, ln. 39 - 40 (translation mine): "See what we have said, namely that the perfection of one person is the cause of the existence of another [person]. [The Father's] own existence is the cause of [the Son's] existence."

22 Ibid., 5, 7, p. 203, ln. $43-47$.

${ }^{23}$ For the same claim elsewhere, cf. Henry of Ghent, $S Q O, 75,2$, f.294vG.
} 
of a person. The hard 'LT' model is consistent with Boethius's concept of a person, and the soft 'LT' model is consistent with Richard of St. Victor's concept of a person.

Boethius's definition (and to a lesser extent Richard's definition) of 'person' was more or less dominant up until John Locke raised the issue of what is required for personal identity. ${ }^{24}$ Locke famously argues that to be the same person requires having the same memories and so to be the same psychological subject (Locke 1979, 335ff.). For Locke sameness of person requires sameness of a first-person point of view or self-consciousness. This psychological criterion is notably absent from Boethius's and Richard's definitions of 'person'.

If one were to accept a Lockean account of personal identity and were a Trinitarian, it would be no surprise to find one advocating ST. If one were not a Lockean regarding personal identity but rather followed the older concepts of 'person' advocated by Boethius or Richard of St. Victor, then one might be inclined toward some species of 'LT'. Karl Barth reported two notable $19^{\text {th }}$ century examples of theologians, namely Anton Günther and Richard Grützmacher, who accepted Locke's definition of 'person' and held that there are three divine persons. These theologians supposed that each divine person is a distinct and discrete divine substance that is self-conscious. On Günther's view the Father alone thinks, "I am God the Father." In 1857 Günther's account of divine persons was condemned by Pope Pius IX because it was thought to be tri-theism. Although Grützmacher did not receive the same papal attention, his position is very similar and so presumably would have received papal condemnation.

One lesson to be learned from this is that we must be careful with our words. What is being asserted when the Latin theological tradition says there are three divine persons? Locke's understanding of 'person' comes much too late on the scene for his account to express what Latin theologians might have meant. Nevertheless, it is not obvious that the Lockean approach is right about personal identity. If Boethius's definition, or Richard's definition, is any guide to the Latin theological tradition, it shows that self-conscious acts were not taken to be essential to personhood even if the aptitude for such acts were implied. Furthermore, these older definitions might well be closer to the truth about personal identity. ${ }^{25}$ I take it that what may in part but need not motivate the foe of ST and friend of 'LT' is her or his rejection of Locke's definition of 'person' and an implicit acceptance of a concept of 'person' along the lines that Boethius or Richard proposed. Pope Pius IX's rejection of Günther's version of ST seems to depend on one of these older definitions of 'person'. Karl Barth ably describes the situation:

\footnotetext{
${ }^{24}$ Prior to Locke, Philip Melancthon's statements about persons seemed to suggest ST to John Calvin. See Karl Barth's discussion of Melancthon and Calvin in Church Dogmatics I.1, p. 358. Further, Rene Descartes's claim that human persons are 'thinking things' shifted focus away from persons as substances capable of intellectual cognition to privileging episodic psychological phenomenon as a criterion for human persons. Also, there is a case to be made that Locke was influenced by some of the Cambridge Platonists, e.g., Ralph Cudworth. Thanks to Douglas Hedley for bringing this to my attention. Cf. Thiel (1991).

${ }^{25}$ Consider Christopher Shield's rejection of the Lockean and bodily-continuity theories in favor of an Aristotelian one that is much like Boethius's and Richard of St. Victor's definitions; cf. Philosophy Bites, <http://philosophybites.com/2008/11/christopher-shi.html>.
} 
What is called 'personality' in the conceptual vocabulary of the $19^{\text {th }}$ century is distinguished from the patristic and medieval persona by the addition of the attribute of self-consciousness. This really complicates the whole issue. One was and is obviously confronted by the choice of either trying to work out the doctrine of the Trinity on the presupposition of the concept of person as thus accentuated or of clinging to the older concept which since the accentuation in usage has become completely obsolete and is now unintelligible outside monastic and a few other studies (Barth 2005, 357).

Barth's judgment was that God is one Lockean person, and that the Father, Son, and Holy Spirit are three different ways or modes of being this person. By contrast, Leftow contends there are three divine persons just in case there are three Lockepersons, that is, God's three distinct streams of consciousness. God is self-conscious three times over. Whereas Barth supposed that distinct streams of consciousness require distinct agents or substances, Leftow disagrees. He claims that numerically the same substance can bear distinct streams of consciousness.

On reflection, one might be justified to suppose that Leftow's position implies one Boethian divine person and three Lockean divine persons. After all, Leftow often refers to God by a personal pronoun ('he'). This Boethian person, God, is not one Locke-person, but three Locke-persons. In any case, Barth did not consider the viability of this move. Perhaps he would have thought it incoherent. But if it is coherent, then perhaps Pope Pius IX would have been less worried about saying that the three divine persons are three Locke-persons.

An advocate of soft 'LT' would argue that it is not clear what we are saying of someone if we say that someone is self-conscious. First, what is it, exactly, to be selfconscious? There are at least three types of consciousness: phenomenal consciousness, access consciousness (also called 'perceptual consciousness'), and introspective consciousness (Armstrong 2004). Second, what is a 'self? Talk of a 'self' seems to require talk of a 'person'. Is a 'self' a Boethian person, a Richardian person, a Lockean person, or something else? But if the concept of 'person' is in dispute, then so too is the concept of 'self' - if there is such a concept. It is noteworthy that Leftow's discussion of God's distinct streams of consciousness is ambiguous; it seems he downplays talk of streams of consciousness and focuses instead upon an agent's life as the index that determines the referent of " $\mathrm{I}$ " in sentences like, "I am God the Father" (Leftow 2004a, 327-328).

We can summarize hard 'LT' and soft 'LT' as follows. On Leftow's hard 'LT' there seems to be one Boethian person who is three Locke-persons. On soft 'LT' there are three Richardian persons. On hard 'LT', the name 'God' refers to God, a single agent. On soft 'LT', the name 'God' refers to any divine person. If asked, "Is God a person?" we should reply, "What is meant by the term 'person'?" If we accept Boethius's definition, then God is just one person. If we accept Richard of St. Victor's definition, then, along with soft 'LT' we would say that there are three divine persons - each of whom is constituted by the singular and communicable divine nature and an incommunicable personal attribute. If we accept Locke's definition, 
then, along with Leftow's hard 'LT' we might say that God is three persons, that is, one agent living three lives simultaneously.

\section{Conclusion: Non-Social 'Latin Trinitarianisms'}

Near the end of Leftow's criticisms of three kinds of ST in "Anti Social Trinitarianism," he invites us to reconsider what 'LT' has, or could have, going for it. A theological strength of 'LT' is that it is unambiguously monotheist, or at least much more unambiguously monotheist as compared to ST. What remain to be seen are the various models available to 'LT' sympathizers and how each model relates to the issue of indexicals and the Trinity.

I have tried to show that there are at least two models of indexicals and the Trinity available to the friend of 'LT'. After we have the metaphysical differences between hard and soft 'LT' ready to hand, in addition to one's account of indexicals and ambiguous tokens, we are in a position to appreciate the way in which each addresses the issue of indexicals and the Trinity. This issue is far from resolved, however. But if we can see what different versions of 'LT' have to offer, then we can begin to assess the options. ${ }^{26}$

\section{Bibliography}

Armstrong, David. 2004. "What is Consciousness?" In Philosophy of Mind: A Guide and Anthology, edited by John Heil. Oxford University Press.

Barth, Karl; Geoffrey W. Bromiley; and Thomas Forsyth Torrance. 2004. Church Dogmatics: The Doctrine of the Word of God As the Criterion of Dogmatics. Vol. 1. Continuum Intl Pub Group.

Boethius. 1973. Theological Tractates. The Consolation of Philosophy. Translated by H. F. Stewart, E. K. Rand, and S. J. Tester. Loeb Classical Library.

Braun, David. 2001. “Indexicals.” Accessed September 14. http://plato.stanford.edu/archives/sum2012/entries/indexicals/.

Brower, Jeffrey. 2004. "Trinity”. In The Cambridge Companion to Peter Abelard, edited by J. Brower and K. Guilfoy. Cambridge University Press.

Brower, Jeffrey E.; and Michael Rea. 2005. "Material Constitution and the Trinity." Faith and Philosophy 22 (1): 57-76.

\footnotetext{
26 Thanks to an anonymous referee for challenging and helpful comments.
} 
Cross, Richard. 2005. Duns Scotus on God. Ashgate Studies in the History of Philosophical Theology. Ashgate Pub Ltd.

- - 2. 2010. "Latin Trinitarianism: Some Conceptual and Historical Considerations." In Philosophical and Theological Essays on the Trinity, edited by Thomas McCall and Michael C. Rea. Oxford University Press.

-_- 2012. "Philosophy and the Trinity". In The Oxford Handbook of Medieval Philosophy, edited by John Marenbon. Oxford University Press.

Davis, Stephen T.; Daniel Kendall; and Gerald O'Collins. 2004. The Trinity: An Interdisciplinary Symposium on the Trinity. Oxford University Press.

Friedman, Russell L. 2010. Medieval Trinitarian Thought from Aquinas to Ockham. 1st ed. Cambridge University Press.

Freidman, Russell L. 2012. Intellectual Traditions at the Medieval University: The Use of Philosophical Psychology in Trinitarian Theology Among the Franciscans and Dominicans, ... Texte Zur Geistesgeschichte Des Mittelalters. Brill Academic Pub.

Gaukroger, Stephen, ed. 1991. The Uses of Antiquity: The Scientific Revolution and the Classical Tradition. 1st ed. Springer.

Henry of Ghent. 1520. Summa Quaestionum Ordinariarium. Edited by I. Badius. 2 Volumes. (Reprint 1953. Franciscan Institute Publications.)

Leftow, Brian. 2004a. "A Latin Trinity". Faith and Philosophy 21: 304-333.

-__. 2004b. "Anti Social Trinitarianism". In The Trinity, edited by. Stephen T. Davis, Daniel Kendall, and Gerald O'Collins. Oxford University Press.

——_. 2007. "Modes without Modalism." In Persons: Human and Divine, edited by Peter van Inwagen and Dean Zimmerman. Oxford University Press.

Locke, John. 1979. An Essay Concerning Human Understanding. Edited by Peter H. Nidditch. Oxford University Press.

Marenbon, John, ed. 2012. The Oxford Handbook of Medieval Philosophy. Oxford University Press.

McCall, Thomas; and Michael Rea, eds. 2010. Philosophical and Theological Essays on the Trinity. Oxford University Press.

Paasch, J. T. 2012. Divine Production in Late Medieval Trinitarian Theology: Henry of Ghent, Duns Scotus, and William Ockham. Oxford University Press. 
Perry, John. 2000. "What Are Indexicals?” In The Problem of the Essential Indexical and Other Essays. Center for the Study of Language and Inf.

Richard of St. Victor. 1958. De Trinitate. Edited by J. Ribaillier. Librarie Philosophique. J. Vrin.

Sennet, Adam. 2011. "Ambiguity." Accessed May 16. http://plato.stanford.edu/archives/sum2012/entries/ambiguity/.

Thiel, Udo. 1991. "Cudworth and Seventeenth-Century Theories of Consciousness". In The Uses of Antiquity: The Scientific Revolution and the Classical Tradition, edited by Stephen Guakroger. Kluwer Academic Publishers.

Tolkien, J. R. R. 1973. The Hobbit, or There and Back Again. Revised. Houghton Mifflin Books for Children.

Van Inwagen, Peter; and Dean Zimmerman, eds. 2007. Persons: Human and Divine. Oxford University Press.

Williams, Scott M. 2010a. "Augustine, Thomas Aquinas, Henry of Ghent, and John Duns Scotus: On the Theology of the Father's Intellectual Generation of the Word." Recherches de Théologie et Philosophie Médiévales, 77(1): 43-49. doi: 10.2143/RTPM.77.1.2050372.

- - . 2010b. "Medieval Trinitarian Thought from Aquinas to Ockham. By Russell L. Friedman." The Journal of Theological Studies 61 (2) (October 1): 833-836. doi:10.1093/jts/flq141.

- - 2011. "Henry of Ghent on the Trinity: Metaphysics and Philosophical Psychology." Unpublished Dissertation, University of Oxford.

- - . 2012. "Henry of Ghent on Real Relations and the Trinity: The Case for Numerical Sameness Without Identity." Recherches de Théologie et Philosophie Médiévales 79 (1): 109-148. doi: 10.2143/RTPM.79.1.2168980. 